
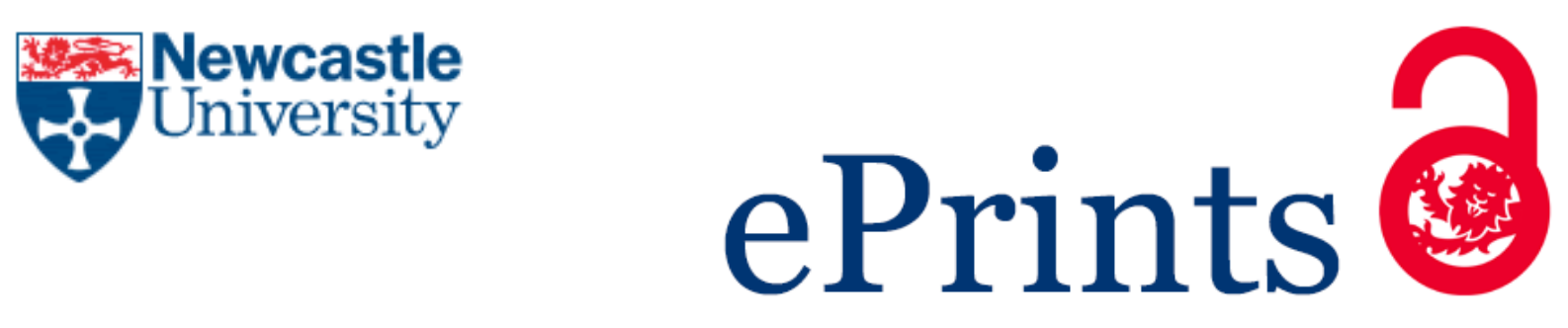

Jackson MPC. A critical examination of Gertrude Bell's contribution to archaeological research in central Asia Minor. In: Gertrude Bell and Iraq: A Life and Legacy. 2017, Oxford: Oxford University Press for the British Academy. Proceedings of the British Academy, volume 205.

\title{
Copyright:
}

(C) The author 2017.

Link to volume:

https://global.oup.com/academic/product/gertrude-bell-and-iraq-9780197266076

Date deposited:

$21 / 08 / 2017$

Embargo release date:

13 April 2019

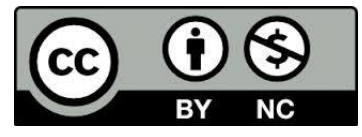

This work is licensed under a Creative Commons Attribution-NonCommercial 3.0 Unported License 


\section{A critical examination of Gertrude Bell's contribution to archaeological research in central Asia Minor}

Mark P. C. Jackson

\section{Abstract}

This paper considers the contribution made by Gertrude Bell to developing archaeological method in the early $20^{\text {th }}$ century and its legacy. The Thousand and One Churches, published in 1909 and written with Sir William Ramsay, remains the key study of Byzantine churches in central Anatolia. While it set high standards in the recording of buildings, it also served to reinforce the culture-historical approaches of the early $20^{\text {th }}$ century. Left behind by most archaeologists in the second half of the $20^{\text {th }}$ century, such approaches have continued in some circles. The paper will consider the extent to which Bell was following and contributing to established archaeological practice. It will consider also the problems of her methodological approach in order to inform a critique of the legacy of her research and to provide insights into her critical thinking and strategies for networking.

Keywords

Binbirkilise, Byzantine, churches, Culture History, William Ramsay, Strzygowski, Orientalism

Biographical note

Mark Jackson is Lecturer in Archaeology and Manager of the Gertrude Bell Photographic Archive at the School of History, Classics and Archaeology Newcastle University. In 
addition to Gertrude Bell, his primary research area is Late Roman and Byzantine archaeology; he leads undergraduate and MA modules and has supervised several PhD candidates. In 2008, he republished (with R. Ousterhout) Ramsay and Bell's The Thousand and One Churches. From 2007-2011, he was Co-director for the Byzantine for the Kilise Tepe Archaeological Project and in 2013 he edited (with C. Nesbitt) Experiencing Byzantium.

\section{Introduction}

Gertrude Bell's contribution to archaeology may seem rather less important than aspects of her later life, but it was Gertrude Bell's love of archaeology and her determination to achieve certain archaeological goals that drove her to travel widely in the Middle East. Through her journeys and research Bell built a familiarity with topography and places as well as a network of contacts both local and international which were to be essential assets in her later political roles during the First World War and its aftermath,

'A.T. Wilson and I spend a considerable part of our time laying down acceptable frontiers by request. It's an amusing game, when you know the country intimately, as I do, thank goodness, almost all of it. Was ever anything more fortunate than that I should have crisscrossed it in nearly every direction? ${ }^{\prime 1}$

This knowledge of the places, people, languages and customs of the Orient was for Bell an asset which made her useful to the British government. The knowledge gained in earlier years driven by archaeological exploration gave her status, identity and a role as an imperial agent at a time of fundamental change in the Middle East for a decade between 1916 and $1926 .{ }^{2}$

\footnotetext{
${ }^{1}$ Newcastle University, Robinson Library, G. Bell Letter 6 December 1918.

${ }^{2}$ E. Said, Orientalism, (Penguin, London, 2003), p.196-7.
} 
Bell's archaeological legacy is multifaceted. The focus of this chapter is the contribution Gertrude Bell made to early developments in archaeological method and interpretation. Her early work, in Turkey between 1905 and 1907 where her archaeological reputation was first established, resulted not only in publications but also in archive material that continues to be of use to archaeologists in the present. ${ }^{3}$ Bell participated in the European scramble to claim and record sites and buildings that were in the process of rapid disintegration. Her interest in the monuments of the Byzantine and early Islamic past and the methodical ways in which she recorded buildings, with plans and photographs to illustrate textual descriptions have remained important recording techniques in archaeology for over a century. ${ }^{4}$ Some of the methods of approach and interpretation adopted in the first decades of the twentieth century on the other hand have proved to be problematic. The influence of other academics on Bell's thinking helps us to see how she developed as an archaeologist and how she engaged with established authorities. This paper will question the extent to which her archaeological interpretations were independent of scholars of the time and the extent to which she conformed in her archaeological interpretations to the prevailing views of those around her, particularly those who had an established status. In her archaeological work therefore, we can gain an insight into her critical thinking and the extent to which she was independent of the influence of others. This approach to her work in the field of archaeology may prove useful to those working on Gertrude Bell's networks and power relations in other contexts including her function as a political officer.

The Thousand and One Churches

\footnotetext{
${ }^{3}$ Newcastle University, Robinson Library, The Gertrude Bell Archive, http://gertrudebell.ncl.ac.uk; and Royal Geographical Society, GB 0402 GLB.

${ }^{4}$ J. Crow, 'Archaeology', in E. Jeffries, J. Haldon and R. Cormack (eds.) Oxford Handbook of Byzantine Studies (Oxford, Oxford University Press, 2008), pp. 47- 58 at pp. 48-9.
} 
Binbirkilise, 'The Thousand and One Churches', is located ca. 29km north of Karaman at the Karadağ, an ancient volcano, on the central Anatolian plateau. Celebrated as the finest collection of church buildings in central Asia Minor, it had captured the imagination of European travellers since the early $19^{\text {th }}$ century. Binbirkilise was reported in the 1830 s in some detail by Hamilton, ${ }^{5}$ and Laborde who produced important drawings of the site published in $1836 .{ }^{6}$ Others made trips in subsequent decades, including for example Davis who described the buildings briefly in $1873 .^{7}$

Towards the end of the $19^{\text {th }}$ century, Charles Wilson, who had visited Binbirkilise with Sir William Ramsay in $1882,{ }^{8}$ wrote in his Handbook for Travellers that the site needed examination by someone 'competent in Byzantine architecture'. 9 A flurry of excursions to Binbirkilise began to answer Wilson's call. Recently discovered photographs of the site in 1887 taken by J.H. Haynes reveal that at the time churches 8 and 13 were still well preserved, but within twenty years both of these buildings were little more than piles of rubble. ${ }^{10}$ In the

\footnotetext{
${ }^{5}$ W. J. Hamilton, 'Notes of a Journey in Asia Minor, in 1837' Journal of the Royal Geographical Society of London, 8 (1838), 137-57 at 154-5; W. J. Hamilton, Researches in Asia Minor, Pontus and Armenia with some account of their antiquities and geology, vol. II (London, John Murray, 1842), p. 316-20.

${ }^{6}$ L. de Laborde, Voyage en Orient, I. Asie Mineure (Paris, 1837) pp. 120-21, plates LXVIII-LXIX.

${ }^{7}$ E. J. Davis, Life in Asiatic Turkey (London, Stanford, 1879), pp. 301-11.

${ }^{8}$ W. M. Ramsay and G. L. Bell, The Thousand and One Churches (London, Hodder and Stoughton, 1909), p. vii.

${ }^{9}$ C. W. Wilson, Handbook for travellers in Asia Minor, Transcaucasia, Persia (London, J. Murray, 1895), p. 158.

${ }^{10}$ R. G. Ousterhout, John Henry Haynes A Photographer and archaeologist in the Ottoman Empire 1881-1900 (Istanbul, Cornucopia, 2011), pp. 105-7; R. Ousterhout, 'Binbirkilise Revisited: The 1887 photographs of John Henry Haynes’ Deltion tes Christianikes Archaiologikes Etaireias 34 (2013), 395-404.
} 
brief report of Binbirkilise which he published in 1903, ${ }^{11}$ John Winter Crowfoot, who went in 1900 with J. G. C. Anderson, bemoaned the tragic annual loss of the buildings in Asia Minor and lamented the scholars, pointing a finger at the historical geographer William Ramsay, who visited such sites only to take away with them a record of a few inscriptions. ${ }^{12}$

...of late Anatolian inscriptions we have recently had a surfeit, but meanwhile the buildings are yearly disappearing. At Yonuslar, for example, in the neighbourhood of Konieh, Prof. Ramsay (Hist. Geog. of Asia Minor, p. 333) mentions "the remains of a fine and large church" : I saw hardly one stone standing upon another in 1900, and the latest visitors to this site are ominously silent (J. H. S. 1902, p. 100). A book, I hope, may not only rescue a few individual monuments, but it may remind epigraphists and others, all in fact who travel with a camera and a measure, that inscriptions are not the only things of interest to the world. ${ }^{13}$

Unable to conduct a fuller architectural study of Binbirkilise in 1901, due to quarantine of boats sailing from Egypt where he was based, ${ }^{14}$ Crowfoot was persuaded to include his survey from 1900, in Josef Stryzgowski’s excitingly titled Kleinasien Ein Neuland der Kunstgeschichte (Asia Minor a New territory of Art history). ${ }^{15}$ The following year, Carl

\footnotetext{
${ }^{11}$ J. W. Crowfoots [sic], 'I. Binbirkilise (Madenschehr)' in J. Stryzgowski Kleinasien Ein Neuland der Kunstgeschichte (Leipzig, J. C. Hinrichs, 1903), pp. 1-20.

12 The attrition at Binbirkilise would have been very apparent to Ramsay who had seen their demise over the previous 25 years since his first visit and perhaps this comment encouraged Ramsay to help Bell with her task.

${ }^{13}$ Crowfoot, Binbirkilise (Madenschehr), p. 2.

${ }^{14}$ Ibid., p. 2.

${ }^{15}$ J. Strzygowski, Kleinasien: Ein Neuland der Kunstgeschichte (Leipzig, J. C. Hinrichs, 1903).
} 
Holzmann, an engineer working on the building of the Istanbul-Bagdad railway, made his own short study. ${ }^{16}$

Szymaszek's reconstruction of the history of contact between Bell and Strzygowski based on Bell's papers has demonstrated that she had developed a great respect for him. ${ }^{17}$ Bell was also influenced by Salomon Reinach the editor of the French journal Revue Archéologique with whom she had made herself popular in Paris and under whose guidance she had learnt much, 'Reinach was much pleased but then he loves me so dearly that perhaps he is not a good judge. He is such a little dear. He has simply set all his boundless knowledge at my disposal and I have learnt more in these few days than I should have learnt by myself in a year' ${ }^{18}$ Reinach asked her to write a review of Strzygowski's 1904 publication on Mshatta, ${ }^{19}$ she revealed in a letter to her step mother not only her admiration for Stryzgowski's work but also her lack of critical academic experience for the task at hand, 'He [Reinach] wishes me to review a new book of Stryzgowski's for the Revue Archéologique - I think I might as well try my prentice[?] hand as it happens to be a Syrian subject which I do just happen to know a very little about. Anyhow it's a jolly lark. ${ }^{20}$

With hindsight, Bell's 'jolly lark' was full of praise for the achievements of the publication including its careful and detailed recording, but failed to pick up on problems in the

\footnotetext{
${ }^{16}$ C. Holzmann, Erläuterungen zu den Skizzen von Binbirkilise (Konia, 1904).

${ }^{17}$ I am most grateful to Dr Maciej Szymaszek for sending me a copy of his very useful study of Bell's correspondence with Strzygowski in advance of its publication. M. Szymaszek 'Josef Strzygowski in the letters and diaries of Gertrude Lowthian Bell', in P. O. Scholz (ed.), Von Biala nach Wien. Strzygowski und die Kunstwissenchaft, (Berlin, Frank \& Timme, 2015), pp. 1-15.

${ }^{18}$ Newcastle University, Robinson Library, G. Bell Letter 11 November 1904.

${ }^{19}$ G. Bell 'J. Strzygowski, Mschatta’ Revue Archéologique, 5 (1905), 431-2.

${ }^{20}$ Newcastle University, Robinson Library, G. Bell Letter 10 November 1904.
} 
methodology; later scholarship subsequently revealed that Strzygowski's conclusions about the building's dates to be too early, but importantly she follows the eminent Strzygowski rather than the much younger Herzfeld whose planning she had noted to be problematic. ${ }^{21}$ Bell could appreciate Strzygowski's skills in observation and recording but she missed an opportunity for a more critical review of Strzygowski's interpretive framework. Her lack of expertise, and the deference for the renowned scholar visible in her review, resulted in praise rather than critical review of his study. Nevertheless as Szymaszek has observed this opportunity seems to have been a turning point in her archaeological career. ${ }^{22}$

Strzygowski's Kleinasien had become in 1903 the most detailed documentation of the Byzantine architecture of Asia Minor; it was also one of the first attempts at its synthetic interpretation. The volume classified the churches of coastal and inland Asia Minor according to their architectural types and considered questions of chronology. It was built on the ideas in his Orient oder Rom $?^{23}$ and provided an explanation, upheld by few today, that the architectural ideas used in churches in Asia Minor spread to the Latin West. ${ }^{24}$

Stryzgowski's Kleinasien was a significant contribution to the subject at the time. It is against this background that Gertrude Bell's first visit of 1905 must be set. Interest in Binbirkilise had never been greater. Momentum for a comprehensive analysis of the site was gathering in

\footnotetext{
${ }^{21}$ E. Herzfeld, 'Der Genesis der islamischen Kunst und das Mashatta-Problem’ Der Islam, 1 (1910), 27-63, 10544; Kleinbauer, Early Christian and Byzantine Architecture, p. ixxv. L. Cooper, 'Archaeology and Acrimony: Gertrude Bell, Ermst Herzfeld and the Study of Pre-Modern Mesopotamia' Iraq 75 (2013), 143-69.

${ }^{22}$ Szymaszek, 'Josef Strzygowski’, 7-8.

${ }^{23}$ J. Strzygowski, Orient oder Rom?: Beiträge zur Geschichte der spätantiken und frühchristlichen Kunst

(Leipzig, J. C. Hinrichs, 1901)

${ }^{24}$ W. E. Kleinbauer, Early Christian and Byzantine Architecture. An annotated bibliography and historiography, (Boston, G.K. Hall, 1992), p. lxxv-lxxvii, 99.
} 
the European scholarly community. A study was needed and although several scholars had laid a foundation, none had managed to complete the task. In the volumes in her library and in entries in her letters and diaries, we can see Bell's appreciation of developing research interest in Binbirkilise and it is testimony to this understanding of the contemporary archaeological interest in the site that she included it on her itinerary overland from Syria to Istanbul.

Two years after its publication, on 11 May $1905,{ }^{25}$ Gertrude Bell arrived at the Karadağ where she stayed until the 15 May 'impelled by' Kleinasien. ${ }^{26}$ Bell's journey from Syria along the south coast of Cilicia and then up through the Taurus mountains to central Anatolia came out in instalments, the latter three articles dealing with Binbirkilise. The pieces were published in Revue Archéologique. ${ }^{27}$ On her way back from Binbirkilise on 16 May, by chance she met Sir William Ramsay in Konya ${ }^{28}$ she discussed with him both the site and an inscription. ${ }^{29}$ Ramsay was prompted to return there himself to follow up their discussion about the inscription which he published later that year. ${ }^{30}$ The fact that Bell, who was at that time a relatively unknown quantity, was able to persuade Ramsay "the foremost authority on

\footnotetext{
${ }^{25}$ Newcastle University, Robinson Library, G. Bell Diary 11 May 1905.

${ }^{26}$ Ramsay and Bell, Thousand and One Churches, p. vii.

${ }^{27}$ G. L. Bell, 'Notes on a Journey through Cilicia and Lycaonia' Revue Archéologique, 8 (1906), 225-52; G. L.

Bell, 'Notes on a Journey through Cilicia and Lycaonia' Revue Archéologique, 8 (1906), 390-401;

G. L. Bell, 'Notes on a Journey through Cilicia and Lycaonia’ Revue Archéologique, 9 (1907), 18-30.

${ }^{28}$ Newcastle University, Robinson Library, G. Bell Letter and Diary 16 May 1905.

${ }^{29}$ Bell, G. L. 'Notes on a Journey through Cilicia and Lycaonia' Revue Archéologique, 8 (1906), 225-52 at 228.

${ }^{30}$ W. Ramsay, 'Inscriptions from BBK'Athenaeum 16 Dec. 1905.
} 
the topography, antiquities and history of Asia Minor" to make a major study with her shows something of her ability to make the most of such a chance encounter. ${ }^{31}$

Having staked her claim in print, her return in 1907 - with Ramsay collaborating on the history and inscriptions - enabled them to address Crowfoot's concerns and to produce a monograph on the scale which he had proposed. The 580-page study they published in 1909 has been described as 'the fundamental publication of some forty church buildings at Binbirkilise'. ${ }^{32}$ The expedition was mounted at the Thousand and One Churches from May to June 1907. Bell arrived at Maden Sheher on 15 May 1907, Sir William Ramsay and Lady Ramsay joined on 24 May and left on 27 June 1907, Bell stayed until 29 June. ${ }^{33}$ Bell's resolve to work at Binbirkilise helped her to break into the Byzantine academic community by enabling her to produce an important volume and to engage as an academic colleague with other scholars in the field.

Ramsay and Bell's research at Binbirkilise marked a new stage in the recording of Byzantine archaeology by making the Karadağ the focus of an expedition over many weeks. The result of their fieldwork on the mountain is a volume based on considerably more intensive analysis than was normal for most projects at the time.

In the Thousand and One Churches we see her first attempt to build on her 'Notes on a Journey' and to establish herself by making a major contribution to the subject. Both her

\footnotetext{
${ }^{31}$ R. G. Ousterhout and M. P. C. Jackson, 'Editors' Forward' in W. M. Ramsay and G. L. Bell, The Thousand and One Churches, with newly digitized original images from Newcastle University and University of Pennsylvania Museum Archives. first published 1909 (Philadelphia, University of Pennsylvania Museum of Archaeology and Anthropology, 2008), ix-xxviii.

${ }^{32}$ Kleinbauer, Early Christian and Byzantine Architecture, p. 92, no. 360.

${ }^{33}$ Bell arrived at Maden Sheher 15/5/1907 (diary), Sir William Ramsay and Lady Ramsay arrived on 24/5/1907 (diary), they left on 27/6/1907 (diary), Bell left on 29/6/1907 (diary).
} 
papers in the scholarly journal Revue Archéologique, ${ }^{34}$ and her books aimed at a popular readership such as Desert and the Sown and Amurath to Amurath, ${ }^{35}$ reflect the way archaeological sites were often published as part of travel narratives. A similar contrast is provided by Sir Mark Sykes in his description of the discovery of the monastery at Mahras Dağ. His narrative in The Caliph's last heritage; a short history of the Turkish empire presents the Byzantine buildings encountered on his journeys in a very different context to that in Ramsay and Bell's study,

For one hour and three-quarters we ascended on our ponies, and then had to abandon them and crawl. I suppose that crawling through a forest growing on a gradient of one foot to five inches, with boulders that fall and branches that fail to support, is child's play to a mountaineer. To me it is painful and terrifying, and it went on for three quarters of an hour, excluding such times as I lay down on the ledge and panted. Well, all things end and so did that horrible ascent; and there hidden in the brushwood, I trust concealed from all European eyes but mine, lay the monastery of grey stone. Some people may like moufflon, and others ibex, but give me a monastery; the only objection to monasteries is that you never know whether they have been bagged by someone else. ${ }^{36}$

'Bagging monasteries' may liven up a text but travelogues did not provide an ideal context for the dissemination of archaeological records, in spite of the fact that this entry included a respectable plan of the church and the location of neighbouring tombs and inscriptions.

\footnotetext{
${ }^{34}$ Op. cit. Footnote 27.

${ }^{35}$ G. L. Bell, The Desert and the Sown (London, Heinemann, 1907); G. L. Bell, Amurath to Amurath (London, W. Heinemann, 1911).

${ }^{36}$ M. Sykes, The Caliph's last heritage; a short history of the Turkish empire (London, Macmillan, 1915), pp. $534-6$.
} 
Indeed although much important evidence recorded for churches in Asia Minor was built up from little more than such short ad hoc visits. It this case, unfortunately, like the church itself hidden in the brushwood, Sykes' important record of the site at Mahras Dağ lay buried from scholars' attention, so that Michael Gough was apparently unaware of Sykes' description when prepared his own publication of Mahras Dağ following an excursion there in 1957 with his team whilst they were working at Alahan. ${ }^{37}$

In contrast to the descriptions of structures and inscriptions cherry-picked along the route of a journey, Ramsay and Bell helped to establish a site-based approach by making a systematic study of the buildings on the Karadağ over several months; the comprehensive nature of their work produced results which the traditional Reisen could not achieve. ${ }^{38}$ In the combination of Ramsay and Bell we see the implementation of a more holistic study of the landscape history of the Karadağ. Building on the pioneering work of Crowfoot, Smirnov, Holzmann and Strzygowski, Bell employed a classificatory approach in order to document and facilitate comparison between the structural forms and details of buildings. Bell industriously corrected the measurements of previous scholars on her field plans and filled in the gaps left by them. Bell's determination and thorough approach to the buildings on the Karadağ set a rigorous standard. Her field notes and published drawings, for example of Church 1 at Madenşehir, reveal the way she re-planned buildings recorded by Crowfoot and Holzmann for her publication, (see Figures 1 and 2).

What Bell and Ramsay achieved at Binbirkilise was the most thorough study of the site and its region ever undertaken and for that reason their work has remained authoritative. The 580-

\footnotetext{
${ }^{37}$ M. R. E. Gough, 'Notes on a visit to Mahras Dağ Monastery in Isauria' Byzantine Studies, 1 (1974), 65-72; R. M. Harrison, 'The Monastery on Mahras Dağ in Isauria' Yayla, 3 (1980), 22-4.

${ }^{38}$ W. H. C. Frend, The Archaeology of Early Christianity A History (Minneapolis, Fortress, 1998), p. 130.
} 
page volume came out quickly in 1909, less than two years after her expedition there with Ramsay.

The Thousand and One churches was dedicated to Strzygowski; Kleinasien was 'our constant companion during many weeks at Maden Sheher' ${ }^{39}$ This is hardly surprising for in 1907 Kleinasien (which contained Crowfoot and Smirnov's earlier studies of Binbirkilise, and Strzygowski's interpretation), was the main publication on the topic. Ramsay and Bell's study, as the next, needed to engage with it. She mislaid the volume temporarily just before they left the site 'We cleared the apse of 11 and opened the narthex of 4. I planned 7, 5 and 1, besides the apse and narthex of the other two. At the last Strzyg was lost, a fearful tragedy! He turned up next day. ${ }^{40}$

Hers was a study primarily of monuments. Churches, subsidiary buildings, and the large complexes of buildings thought to be monastic at Değle were recorded, but not smaller houses whose door lintels were often the only parts standing. ${ }^{41}$

Measured drawings in plan and architectural details in section, were complemented by written descriptions, and copious photographs of both building elevations and architectural details. Bell's study discusses architectural form and issues of masonry style, together with the decorative carving on blocks in conjunction with Ramsay's inscriptions and issues of relative phasing.

Most European scholars, travellers and architects of Bell's time were financed by foreign governments, universities or learned societies such as the Royal Geographic Society or the British School at Athens whose Byzantine Research Fund supported much work on

\footnotetext{
${ }^{39}$ Ramsay and Bell, Thousand and One Churches, p. v.

${ }^{40}$ Newcastle University, Robinson Library, G. Bell Diary 24 June 1907.

${ }^{41}$ Ramsay and Bell, Thousand and One Churches, p. 9.
} 
Byzantine monuments in the late $19^{\text {th }}$ and early $20^{\text {th }}$ centuries. ${ }^{42}$ The financial support Bell received from her father Hugh Bell, who had taken over the iron-working business established by her grandfather Isaac Lowthian Bell offered her academic independence. Bell was not constricted in the same way by obligations to sponsors when in the field, or with distracting responsibilities at home; her work ethic and productivity seem unaffected by the fact she was essentially accountable to herself. She does however keep her father, and her stepmother Florence, well informed of progress. Gertrude wrote,

We are getting so much material that it will certainly make a book. One plan is that Sir W. shall write the historic and epigraphic part and I the architectural. I think it will be well worth doing, for this is the first time that an accurate study has been made of any one district in these parts; hitherto people have only travelled through and seen what they could see and gone on. We shall certainly be able to contribute a great deal to the knowledge of such settlements as this must have been and for my part I have found Strzygowski out in half a dozen errors to say nothing of the general and fundamental error of his dating. So you see we have not wasted time or money and I look forward to a delightful winter at home drawing my plans and writing my part of the book.... It will be a very dull book, you understand, but I intend it to be magnificently illustrated. ${ }^{43}$

Bell, it appears may have needed to justify to her step mother the expense, but she is also concerned to point out here very clearly her problems with Strzygowski's work.

In his recent study of communication between Strzygowski and Bell, Szmaszek has shown that from about 1904 until 1910, Bell came to see Strzygowski as something of a mentor in

\footnotetext{
${ }^{42}$ Frend, The Archaeology of Early Christianity, p. 130.

${ }^{43}$ Newcastle University, Robinson Library, G. Bell Letter 8 June 1907.
} 
her understanding of architectural history. ${ }^{44}$ Szmaszek has noted the importance of the marginalia written by Bell in her copy of Strzygowski which accompanied her in the field and the existence of a notebook in the Bell archive entitled Kleinasien. ${ }^{45}$ This notebook contains Bell's hand-written notes made from Kleinasien that repeat key points from Strzygowski's argument. The marginalia and the notebook demonstrate her close scrutiny of his volume (see Figure 3).

In May 1907, three American archaeologists who were pupils of Sterrett: Mr Olmstead, Mr Wrench and Mr Charles, who had come to see Ramsay, arrived from the Cornell Archaeological Expedition. ${ }^{46}$ Bell wrote with great interest to her mother about the Americans' findings, 'The Americans have been very useful today for they have been all about picking up scraps of pottery and found some of many periods. The most interesting are those which exactly resemble Mycenaean ware and are no doubt of that period of civilisation. They have also found flint knives. ${ }^{47}$

Their discoveries led Ramsay to search for pre-Hellenic material by digging trenches at Değle. In spite of this, neither Ramsay or Bell took further this work on the pottery. Ramsay's 'fragments' were sadly lost in transit by the servants. ${ }^{48}$

\footnotetext{
${ }^{44}$ M. Szmaszek, 'Josef Strzygowski'.

${ }^{45}$ Bell Miscellaneous Collection: Odds and ends 6. Notebook. Kleinasien written inside front cover. Notes on Hellenistic and Byzantine church architecture.

This notebook is referred to by Szymaszek (forthcoming: fn. 16).

${ }^{46}$ Newcastle University, Robinson Library, G. Bell Diary 27 May 1907; Ramsay and Bell, Thousand and One Churches, p. 3.

${ }^{47}$ Newcastle University, Robinson Library, G. Bell Letter 28 May 1907.

${ }^{48}$ Ramsay and Bell, Thousand and One Churches, p. 10.
} 
'Except for the German excavations at Boghaz Keui, and some Russian diggings at Ani', Bell wrote, she and Ramsay were 'the first to put spade to soil in the interior of Asia Minor'. ${ }^{49}$ Gertrude used her contacts to pull strings in order to gain official support for the work,${ }^{50}$ but the permission granted does in part help to explain the kind of archaeological fieldwork in which they engaged. The day before she began at the site she wrote, 'There are great agitations about my work because my trade does not allow me to dig and I am known to have sent up spades. I do not know how things will turn out' ${ }^{51}$ but then later 'I hear from Konia that the Vali has received special instructions from Constantinople [Istanbul] that he is not to interfere with us and to give us all assistance he can. I expect that's the Grand Vizier, Ferid Pasha; he and Hamdy Beg have stood by us like men. ${ }^{52}$

The final publication makes clearer their position, 'Moreover, our permission from the Turkish Government did not grant the right to make elaborate excavations; but all the officials were very well disposed to us, and not inclined to make too careful scrutiny of the extent of our work' ${ }^{53}$

In fact it seems that she was neither allowed, nor was she attempting to conduct a stratigraphic excavation along the lines pioneered elsewhere in the Mediterranean and Britain since the 1870 s. ${ }^{54}$ 'Clearance' of rubble revealed hidden foundations of walls in order to secure the drawing of an accurate plan (See Figure 4). She seems not to have planned the

\footnotetext{
${ }^{49}$ Ramsay and Bell, Thousand and One Churches, p. 299.

${ }^{50}$ E. Eldem, Nazll's Guestbook Osman Hamdi Bey's Circle (Istanbul: Homer Kitabevi, 2014), pp. 94-101.

${ }^{51}$ Newcastle University, Robinson Library, G. Bell Diary 14 May 1907.

${ }^{52}$ Newcastle University, Robinson Library, G. Bell Letter 8 June 1907.

${ }^{53}$ Ramsay and Bell, Thousand and One Churches, p. 9.

${ }^{54}$ B. G. Trigger, A History of Archaeological Thought (Cambridge, Cambridge University Press, 1989), pp. $196-7$.
} 
buildings' collapse or collected artefacts during the process, and never links pottery or coins to building stratigraphy or uses them to aid building chronology.

Ramsay, who had received the first grant from the Hellenic Society for his work on antiquity and early Christianity in Asia Minor in $1881^{55}$ estimated that the cost of a full study of Binbirkilise would have amounted to at least $£ 5,000$. Frend lamented that Christian archaeology (at Binbirkilise) could not compete for funds in the early $20^{\text {th }}$ century with archaeology of other periods. ${ }^{56}$ And yet Ramsay's comment is telling, 'Even if we had had the money, there was no apparent prospect that a thorough excavation would produce any results commensurate with the outlay. The city was inhabited by a poorly educated and rustic population, and there was no hope of any important epigraphic, still less of artistic discoveries ... . ${ }^{57}$ Ramsay's priorities were epigraphy and potential artistic discoveries, and while Bell's approach to architecture might have produced some useful plans and relative phases of buildings, her lack of attention to soil stratigraphy and finds helps to reinforce why they did not attempt to find such funding. These approaches which have persisted help to illustrate why the study of Byzantine domestic archaeology was neglected then and has only recently been subject to study by Byzantine archaeologists in Turkey. ${ }^{58}$ More extensive excavations, using the research objectives and field methods employed by Ramsay and Bell would not have served well the domestic areas of the site.

We have here a key case study in the careful gathering together of source material in what the editors of the Oxford Handbook of Byzantine Studies refer to as 'the instrumental, rather than

\footnotetext{
${ }^{55}$ Kleinbauer, Early Christian and Byzantine Architecture, p. xlvi.

${ }^{56}$ W. H. C. Frend, The Archaeology of Early Christianity A History (Minneapolis: Fortress Press, 1998), p. 135.

${ }^{57}$ Ramsay and Bell, Thousand and One Churches, p. 9.

${ }^{58}$ M. Jackson, 'Byzantine Settlement at Kilise Tepe in the Göksu Valley', in M. C. Hoff and R. Townsend (eds.)

Rough Cilicia New Historical and Archaeological Approaches (Oxford, Oxbow, 2013), pp. 219-33 at 219-21.
} 
the interpretational, tradition', "by the former, we mean those disciplines which are primarily concerned with the preparation and analysis of source material of one type or another, without which it must reasonably be conceded that no more broadly based interpretative or generalizing study can properly be effected". ${ }^{59}$ This kind of recording and the ideas behind it remain a fundamental part of Byzantine architectural and archaeological studies.

the close examination - that is, on the ground and in situ - of individual buildings [which] continues to sustain and inform all subsequent analyses. Reading the archaeological record remains a basic and indispensable tool, whether excavated remains, published reports, or standing walls. In this regard the positivist approach, while not in vogue according to current academic trends, cannot yet be relinquished by the Byzantine architectural historian. An accurate architectural history cannot be written without buildings, and the architectural historian should be able to "read" a building with the same nuance as a philologist would apply to a text ... Indeed, familiarity with the building lends authority to all other approaches. ${ }^{60}$

Ramsay and Bell were not just creating a comprehensive checklist or catalogue of the sites, they were both making a record, and through doing this, seeking to interpret these previously unstudied places. Much of the record that we have to work with today is based on what they considered worthy of being recorded, thus the ideas behind their methods and their decisions

\footnotetext{
${ }^{59}$ E. Jeffreys, J. Haldon and R. Cormack, 'The discipline' in E. Jeffreys, J. Haldon and R. Cormack (eds.) The Oxford Handbook of Byzantine Studies (Oxford, Oxford, 2008), pp. 3-20, at p. 9.

${ }^{60}$ M. J. Johnson, R. Ousterhout and A. Papalexandrou, 'Introduction: Approaches to Byzantine Architecture and the Contribution of Slobodan Ćurčić', in M. J. Johnson, R. G. Ousterhout and A. Papalexandrou (eds.) Approaches to Byzantine Architecture and Its Decoration Studies in Honor of Slobodan Ćurčić (Farnham,
} Ashgate, 2012), p. 13. 
of what to record should not be considered purely objective; they continue to have implications for those wishing to use their archive.

There was a desire to make sense of this physical legacy of past society. Bell participated in an approach which sought also to explain the origins and influences of architectural types she encountered. ${ }^{61}$

Bell used three main approaches. The first was to describe each building in detail, but this was not the end result. She considered the types in groups and considered their possible functions before discussing the origins of different influences in a combination of art historical and typological/evolutionary method.

Ramsay's contribution centred on the use of epigraphy to suggest a date, or function, for the buildings. The section on the epigraphy was separated from that of the buildings. This reflects the authorship of the chapters, but also the way in which the disciplinary subjects are published in parallel. An inscription might suggest a funerary chapel but that might not be immediately apparent from the discussion of the church. Ramsay's description of the funerary inscription set up by Stephanus in memory of his daughter, for example, that provides the reason for the construction of Church 3, is separated from Bell's architectural description of the church to such an extent that the caption of her photograph showing one half of the inscription mentioned only the moulding. This provides an excellent example of the separation between approaches to text and material culture. ${ }^{62}$

Application of a functional approach was important in 1909, but buildings were sometimes ascribed a function without adequate evidence. A monastic function for example was all too liberally attributed to structures by Bell and other early scholars and travellers because among

\footnotetext{
${ }^{61}$ C. Mango, Byzantine Architecture, (London, Faber, 1986), p. 7.

${ }^{62}$ Ramsay and Bell, Thousand and One Churches, pp. 53-9, p. 529.
} 
other examples because they were located on a hill, or in an isolated place. ${ }^{63}$ Such expectations arise from the narrative framework imposed on the material.

Nearly a century after Ramsay and Bell's Thousand and One Churches, Alcock criticised the study of cult places in Greece for the way focus was on the plan of architecture without attention given to 'their spatial dimension in the regional geography of cult distribution' ${ }^{64}$ Such criticisms might be directed broadly at Byzantine archaeologists too whose studies of churches may take a similar approach when they are decontextualised.

Ramsay, a pioneer of Historical Geography, complemented Bell by taking a wider perspective of the landscape in terms of both time and space. He was able to tie Bell's detailed descriptions of the buildings at Binbirkilise to questions of topography and history. Ramsay was interested in the physical setting of the monuments such as the location of natural features, caves, water sources and hill tops. He considered the enduring nature of the religious topography of the Karadağ, particularly the association of mountain tops and caverns with Anatolian religion. He saw the choice of mountain top locations of several churches, such as Mahaletch, as the continuity into the Byzantine period of an ancient understanding of place visible in the pre-classical inscriptions of the Karadağ (the church and memorial chapel to Leo at Mahaletch were located some $20 \mathrm{~m}$ south of an earlier monument). ${ }^{65}$ Ramsay also brought his historical knowledge so that together they could tie

\footnotetext{
${ }^{63} \mathrm{~S}$. Hill, 'When is a monastery not a monastery?', in M. Mullett and A. Kirby (eds.), The Theotokos Evergetis and eleventh-century monasticism, Belfast Byzantine Texts and Translations, 6.1 (Belfast, Belfast Byzantine Enterprises, 1994), pp. 137-145; V. G. Kalas 'Early explorations of Cappadocia and the monastic myth' Byzantine and Modern Greek Studies, 28 (2004), 101-19.

${ }^{64}$ S. Alcock, Graeca Capta the landscapes of Roman Greece (Cambridge, Cambridge University Press, 1993) p. 173.

${ }^{65}$ Ramsay and Bell, Thousand and One Churches, p. 19.
} 
their studies into a broader historical and topographical narrative. They wrote the sections of the publication separately, but the way they reported their fieldwork reveals that they tested their interpretations of each building on site with the evidence before them. In a process of lively dialogue on site at each building, ${ }^{66}$ Bell worked with Ramsay to combine analyses of every aspect of the buildings' architecture.

They also record information about relic fruit trees and even fauna of the mountain to discuss the nature of the exploitation of the land by the Byzantine populations. ${ }^{67}$ There are seeds here of an attempt to achieve a more comprehensive treatment of entire landscapes developed in the Mediterranean in the second half of the $20^{\text {th }}$ century. ${ }^{68}$

The attention given by Bell to the plans and decoration of churches and her attempts to group them into types reflects the fact that typological analysis was one of the guiding principles of $19^{\text {th }}$ and early $20^{\text {th }}$ century archaeology. Typological analysis went beyond the classification of artefacts by placing them into sequences according to developments in their attributes that enabled them to be put into a hypothetical chronological order ${ }^{69}$ Drawing on scientific taxonomy, the typological approach was enhanced by a pseudo-biological evolutionary analogy or by ideas about functional development. Bell tended to establish the chronology of building types using the relative stratigraphical phasing of the architectural, masonry and decoration types, rather than relying on comparison of form alone. Proponents of early studies of architecture often explained archaeological change by the evolution of ideas, and

\footnotetext{
${ }^{66}$ Ramsay and Bell, Thousand and One Churches, p. xxxi.

${ }^{67}$ Ramsay and Bell, Thousand and One Churches, pp. xxxii, 27, 31-32.

${ }^{68}$ G. Barker and D. Mattingly, 'General Editors' Introduction: The POPULUS Project' in J. Bintliff and K. Sbonias (eds.) Reconstructing Past Population Trends in Mediterranean Europe (Oxford, Oxbow, 1999), pp. iiiix.

${ }^{69}$ K. Greene and T. Moore, Archaeology: An Introduction (Abingdon, Routledge, 2010), pp. 24-25.
} 
then, as culture-historical approaches developed, by arguing for the diffusion of ideas and the migrations of people. ${ }^{70}$ In the case of Binbirkilise the historical narrative Ramsay and Bell finally proposed is structured around the Arab incursions of the $7^{\text {th }}-8^{\text {th }}$ centuries. The Arab invasions are used to explain the end of the first phase of the early buildings at the foot of the mountain at Madenşehir from where a shift took place to a plateau at Değle high up in the mountain in the $7^{\text {th }}$ century, ${ }^{71}$ before renewed occupation and restoration took place at Madenşehir after the Arab wars.

The architectural period which followed the Arab wars was considered to represent a phase typified by a decline in standards that continued until it stopped finally with the arrival of a new migrating ethnic group in the form of the Selcuk Turks. Thus she argues for the temporary inventiveness of central Anatolian people in the Byzantine period which manifested itself in independent architectural forms. There was a general assumption that form would decline through time. The destruction of early phases, and of later buildings and phases, was explained by the invasion by an army of the religiously and ethnically distinct Arab and subsequently Selcuk empires.

A significant problem remained nevertheless, that without dating evidence for many of the buildings key points in the chronology were fixed by supposition, for example the suggestion that all church buildings stopped with the arrival of the Selcuks seems unlikely given that Bell had encountered Christian communities in the wider region, for example at Sille near Konya. ${ }^{72}$ The tone is far from neutral,

\footnotetext{
70 Trigger, History of Archaeological Thought, pp. 148-51.

${ }^{71}$ Ramsay and Bell, Thousand and One Churches, p. 13.

${ }^{72}$ G. L. Bell, 'Notes on a Journey through Cilicia and Lycaonia' Revue Archéologique, 9 (1907), 18-30 at 19-27.
} 
'The date at which the creative faculty of Oriental architects came to an end corresponds with the conquest of Asia Minor by the Selcuks; it seems therefore not unreasonable to suppose that it was not until that great birth-place of architectural motifs, Asia Minor, was severed from the Eastern Empire, that invention ceased' ${ }^{73}$

Not having independent dating evidence for many of the buildings resulted in fitting the structures to a historical narrative, to which in fact they may or may not have belonged. This narrative is used then to suggest dates back onto the building groups and then to reinforce historical interpretations. The buildings are dated by the very political events they are used to explain. Fixed dates for construction phases are so important if the context in which they occurred is to be understood..$^{74}$

In 1947, in a Lecture on Medieval architecture at the British Academy, J.B. Ward-Perkins drew attention to the use of relative chronologies generated using similar techniques, 'The method is dangerous only when it is used, not as an analysis of the principles embodied in an objectively established series of facts, but as itself the criterion by which the facts are to be established' ${ }^{75}$ The re-dating of key churches using scientific techniques such as dendrochronology and radiocarbon dating has had considerable impact on architectural typologies dated previously by relative chronologies. ${ }^{76}$ At Binbirkilise the dating of the churches remains untested ever since and relies mostly on the data collected by Ramsay and

\footnotetext{
${ }^{73}$ Ramsay and Bell, Thousand and One Churches, p. 301.

${ }^{74}$ Johnson, Ousterhout and Papalexandrou, 'Introduction: Approaches to Byzantine Architecture', p. 12.

75 J. B. Ward-Perkins, 'The Italian element in Late Roman and Early Medieval Architecture' Proceedings of the British Academy, 33 (1947), 1-32 at 10.

${ }^{76}$ Johnson, Ousterhout and Papalexandrou, 'Introduction: Approaches to Byzantine Architecture', p. 12.
} 
Bell over a century ago. The careful analysis of the details they, and others, recorded do however enable scholars today to reconsider the chronologies they proposed. ${ }^{77}$

At a greater scale, Strzygowski had linked architectural forms to the regions in which they were found and by comparison of close examination of their characteristics to seek origins of particular forms. Thus the architectural history of Asia Minor was tied in to a metanarrative development of early Christian architecture as was typical of early $20^{\text {th }}$ century Culture History. In his later work he linked the architectural types also to ethnic groups. ${ }^{78}$

In Part III of the Thousand and One Churches, Bell begins by contrasting the Hellenistic influence of the coast with the Oriental character of the plateau,

One of the most remarkable experiences of travel is that which assails him who passes from the seaboard of Asia Minor and gains the central plateau. He leaves behind him a smiling country full of the sound of waters, with fertile valleys, hills clad in secular forests, coasts that the Greek made his own, setting them with cities, crowning them with temples, charging the very atmosphere with the restless activity of his temper ... the fruit gardens dwindle and disappear as the line climbs up to Eskisheher - the traveller looks round and sees that every feature of the landscape has suffered change ... It is Asia, with all its vastness, with all its brutal disregard for life and comfort and amenities of existence; it is the ancient East, returned, after so many millenniums of human endeavour, to its natural desolation. If this is the first it is also the final impression. The further the traveller goes, the more thoroughly he studies the vestiges

\footnotetext{
${ }^{77}$ Ousterhout, 'Binbirkilise Revisited' pp. 402-3.

${ }^{78}$ W. E. Kleinbauer, Early Christian and Byzantine Architecture, pp. 1xxi-1xxxi; A. J. Wharton, Refiguring the Post Classical City Dura Europos, Jerash, Jerusalem and Ravenna (Cambridge, Cambridge University Press, 1995), pp. 1-14; C. Maranci, Medieval Armenian Architecture Constructions of Race and Nation (Leuven,
} Peters, 2001). 
of many decayed civilisations, old and new and all alike decayed, the more deeply will he be convinced of the Asiatic character of the land. Race, culture, art, religion, pick them up at any point you please down the long course of history, and you shall find them to be essentially Asiatic. ${ }^{79}$

She argues that there is an Asiatic character of civilisations and that this character is visible also in their remains: reduced to decay by the 'natural desolation' of the environment. As with many scholars at the time who used the environment to explain differences in societies and societal change between regions, Bell saw the environment as deterministic. ${ }^{80}$ She considered that societies in Asia were eventually determined by their environment.

The discussion in the chapter which follows is mostly a description of the architectural types which she had identified, but it also engages in a search for origins and influences on the central Anatolian structures. Bell's explanatory model suggests that 'Oriental influence' on successive groups on the plateau comes through the continuity and evolution of ideas set against the backdrop of environmental determinism. These origins are sought in Asia.

... The old civilisations coloured and changed the new; the primeval faiths, calling themselves by other names, continued to rule the minds of men; the arts, turned to fresh uses, still drew their inspiration from an Oriental source. The East pursued its deep and salient way, assimilating what was brought to it and passing it out again marked with its own stamp. It is from this aspect that I have found myself forced to regard the Christian antiquities of the Anatolian plateau if I would arrive at any satisfactory understanding of them. The explanation of these ruins, so far as it is as yet

\footnotetext{
${ }^{79}$ Ramsay and Bell, Thousand and One Churches, pp. 297-8.

${ }^{80}$ B. G. Trigger, A History of Archaeological Thought (Cambridge, Cambridge University Press, 1989), pp. 110-11.
} 
possible to offer an explanation, is to be sought in the architectural traditions of Asia. Types and technic must be traced back directly to earlier generations of Oriental builders, or indirectly to the same fountain-head through Hellenistic art which was itself, as were its creators, so strongly Orientalised. ${ }^{81}$

In seeing the origins of the regional architectural forms as heterogeneous but Asiatic, she was arguing within a framework of cultural evolutionism, common in the late $19^{\text {th }}$ century, which saw the Orient distinct from the West and the Mediterranean.

Strzygowski has argued for the precursors of the domed basilica, octagon, and domed cruciform churches in Eastern or Hellenistic art rather than coming from Rome. ${ }^{82}$ This was important because he had argued that the Romanesque architecture of northern Europe travelled from the Hellenistic East from Egypt, Syria and Asia Minor. ${ }^{83}$ Strzygowski had noted that the timber-roofed 'Hellenistic' church basilicas of the West coast of Asia Minor contrasted with the architectural ideas developed on the plateau; he saw these to have been influenced from the East. ${ }^{84}$ By the time Bell was writing, Strzygowski had been criticised by Millet in a review of Kleinasien. ${ }^{85}$ She continued, with qualification,

Probably it would be true to say that along the coasts of Asia Minor the Hellenistic influence was predominant, while upon the plateau the unadulterated East,

\footnotetext{
${ }^{81}$ Ramsay and Bell, Thousand and One Churches, p. 298.

${ }^{82}$ Strzygowski, Kleinasien, p. iv.

${ }^{83}$ Strzygowski, Kleinasien, p. 230.

${ }^{84}$ Strzygowski, Kleinasien, p. iii.

${ }^{85}$ G. Millet, 'L’Asie Mineure: Nouveau domaine de l'histoire de l'art' Revue Archéologique, 5 (1905), 93-105.
} 
Mesopotamia, Persia, Armenia, held the greater sway. The materials available for the forming of such a judgement are however too scanty... ${ }^{86}$

She goes on to group the buildings in central Anatolia by type and to describe the details of each form. ${ }^{87}$ She follows the structure of Strzygowski's Kleinasien. Her analysis contributes by discussing in detail the examples of church forms: the basilica, cruciform, octagon and vault.

She sought to make sense of similarities between the forms; ultimately the academic purpose of this approach was to contribute to an understanding of the origins and influences of the architectural forms. But as Mango points out, the weakness with this typological approach is its abstraction from reality. ${ }^{88}$

This abstraction was precisely the problem Bell encountered in her synthesis of churches in central Asia Minor. Her two summary propositions were: the great variety of architectural types 'there is no end to the imagination of the architects' and 'the marked differences in the architecture of districts very closely related geographically'. ${ }^{89}$ There were so many different types within and between each locality that in reality it was very difficult to arrange them into meaningful groups or sequences.

A key point for Bell was that there were significant local differences in the regional architecture of the Kara Dagh, Hassan Dagh and Karadja Dagh 'districts which are geographically very closely related together'. ${ }^{90}$

\footnotetext{
${ }^{86}$ Ramsay and Bell, Thousand and One Churches, p. 298.

${ }^{87}$ Ramsay and Bell, Thousand and One Churches, pp. 297-489.

${ }^{88}$ Mango, Byzantine Architecture, p. 7.

${ }^{89}$ Ramsay and Bell, Thousand and One Churches, pp. 299-301.

${ }^{90}$ Ramsay and Bell, Thousand and One Churches, p. 301.
} 
'In short, the peculiarities of each district are so salient that I should be much surprised if every separate small artistic centre on the Anatolian plateau were not found to have a separate school of its own. And this conjecture indicates the nature of the inference that must necessarily follow' ${ }^{91}$

She concluded the art could not be imported [e.g. from Rome] but rather was a product of local invention. Thus she argued,

'The art of Central Asia Minor was not imported; an imported art would have been more homogenous. The builders were working within the limits of a native art indigenous to the soil, but within limits they worked with extreme freedom - with the freedom of creators thoroughly conversant with the laws that custom and tradition had imposed upon them'. ${ }^{92}$

There is a freedom of creation within inherited constraints. This regional inventiveness apparently argues against a diffusion of ideas from outside; invention rather than borrowing.

In discussing the domed octagon, she follows Strzygowski,

'I have described the general attributes of the architecture of the plateau in almost the same terms and drawn from the fact the same conclusion as that which Strzygowski has applied to the octagon. The details are worked out freely by local builders, but the inspiration is derived from a common source, and that source is to be looked for in the architectural traditions of Asia. The centralised church, whether it be octagonal or

\footnotetext{
${ }^{91}$ Ramsay and Bell, Thousand and One Churches, p. 302.

${ }^{92}$ Ramsay and Bell, Thousand and One Churches, p. 302.
} 
cross-shaped ... is strongly Oriental and appears in Europe under Oriental influence' ${ }^{93}$

On the issue of whether Armenia borrowed from Constantinople, or vice versa Bell writes, 'I do not venture to decide' ${ }^{94}$ Her views about the errors of previous scholars are put forcefully in private correspondence to her step mother. ${ }^{95}$ But although at times she argued against points held by Strzygowski and others, ${ }^{96}$ as Lienhardt noted, Bell avoided contradicting Strzygowski’s ‘dramatic Asia Minor theory’. 97

She argued for a complex locally invented architecture which seemed different in character to that of the coast. She maintained that although the wide variety of types reflected a local inventiveness, this architecture nevertheless had characteristics, like the landscape, which were Oriental.

In subsequent decades, Strzygowski was to develop his argument for a of diffusion ideas from the east to the west. ${ }^{98}$ Her apparent deference to Strzygowski as the established authority means that she contextualised her own study within his framework, in spite of the fact that the eclectic nature of the types made the links difficult to demonstrate - here she missed an opportunity to call into question the diffusionist approach on which some of his ideas relied and on which he would build in subsequent years. Her results about the types on the central Anatolian plateau in fact might have been used to refute a diffusion of ideas from

\footnotetext{
${ }^{93}$ Ramsay and Bell, Thousand and One Churches, p. 434.

${ }^{94}$ Ramsay and Bell, Thousand and One Churches, 427.

${ }^{95}$ Newcastle University, Robinson Library, G. Bell Letter 8 June 1907.

${ }^{96}$ Kleinbauer, Early Christian and Byzantine Architecture, p. xliii.

${ }^{97}$ R. Lienhardt, 'The Great Basilica, Church No. 1, at Bin Bir Kilise in Anatolia' Journal of the Society of Architectural Historians, 24.4, (1965), 300-3 at 300.

${ }^{98}$ Maranci, Medieval Armenian Architecture.
} 
further east since in fact there was no direct trajectory. In view of the polemical trajectory that Strzygowski's ideas would take in subsequent decades built on the unsound diffusionist approach, one might have hoped for a more robust qualification of his method in the light of Bell's results. At University, Bell was celebrated for her willingness to challenge academic authority. In her architectural interpretations we see that Bell applied industriously the established approaches of her time: her records of buildings remain invaluable and though her interpretations have endured for over a century they are not surprisingly ready to be reevaluated.

With hindsight we might be tempted to ask whether she understood fully the implications of her critique of his perspective or whether she was tempered by his academic status. Perhaps the respect for his rigorous approach to standards of recording led to an acceptance of other aspects of his thinking which, with the benefit of hindsight, was uncritical on her part. One might wonder whether she had a blind spot for taking ideas through to their logical conclusion or whether this was not a perspective which she saw as problematic. The significance of such archaeological and art historical interpretations offers the opportunity to consider also the contributions and perspective brought by Bell, as other scholars of the time, to the constructions of national identities in the early $20^{\text {th }}$ century “... historiographic investigations allow us to appreciate art history's disciplinary influence in the mythopoetic construction of nations and empires". 99

In view of her later influence on Middle Eastern politics, an appreciation of the approaches and influences of Gertrude Bell's archaeology helps us to contextualise her theoretical ideas. We see that they were sometimes problematic and that she could be influenced by others (as

\footnotetext{
${ }^{99}$ K. Kourelis, 'Byzantine Houses and Modern Fictions Domesticating Mystras in 1930s Greece'. Dumbarton Oaks Papers, 65/66 (2011-2012), 297-331, at 298.
} 
noted by Lawrence). They may also help to explain an aspect of the perspective from which she came and provide more context for her role in the creation of the modern state of Iraq.

\section{Conclusions}

As one of very few women leading expeditions and publishing results of archaeological research in Asia Minor at the time, Bell not only paid for, but also masterminded the expedition to Binbirkilise with Ramsay. No-one has since attempted a field study at the Karadağ on such a scale; a review of the monuments surviving at Binbirkilise was carried out by Eyice and some further fieldwork has now been carried out at Değle by M. Ahunbay and T. Saner. ${ }^{100}$

With the disappearance of so many of the monuments over the past century, Bell's descriptions, photographs and plans of the churches and buildings at the Karadağ represent priceless documentation. ${ }^{101}$ Many of her field notes were made in the books of her own library which travelled with her in the field. One can sit today with her own letters, diaries and photographs, and with her library of books reading the annotations she made to herself in the field.

\footnotetext{
${ }^{100}$ S. Eyice, Karadağ (Binbirkilise) ve Karaman çevresinde arkeolojik incelemeler Recherches archéologiques à Karadağ (Binbirkilise) et dans la région de Karaman (Istanbul, publisher, 1971); M. Ahunbay and T. Saner, 'Karaman (Binbirkilise)-Silifke (Ayatekla-Mylai) Araştırmaları [Karaman (Binbirkilise)-Silifke (AyateklaMylai) Research]' Araştırma Sonuçları Toplantısı, 18.2 (2001), 273-8.

M. Ahunbay, and T. Saner, 'Binbirkilise ve Ayatekla'da (Meryemlik) 1998 Araştırmaları [Research at Binbirkilise and Ayatekla (Meryemlik) 1998]' Araştırma Sonuçları Toplantısı, 17.1 (2000), 39-48. ${ }^{101}$ Johnson, Ousterhout and Papalexandrou, 'Introduction', p. 11.
} 
The dedication in the front of the Thousand and One Churches to Strzygowski appears to reflect the admiration she had for him that is expressed elsewhere in her archive and her published reviews. ${ }^{102}$ She showed little of the combative spirit for which she is sometimes known when considering methodology. Instead her contribution to the book with Ramsay follows the methodology of the day in spite of the fact that the method itself had problems. She carefully qualified the potential of the conclusions she drew from the evidence but did not overtly disagree with other scholars' work; in is noteworthy that in spite of her research she chose not to criticise Strzygowski one of the most celebrated and controversial scholars of his time when in fact her findings might have tempered his later interpretations.

In this context T.E. Lawrence's comments appear particularly astute, 'Gertrude was not a good judge of men or situations: and was always the slave of some momentary power: at one time Hogarth, at another Wilson, at another me, at last Sir Percy Cox. She changed her direction each time like a weathercock: because she had no great depth of mind. But depth and strength of emotion - Oh Lord yes' ${ }^{103}$

Such interpretations may be too simplistic given that Bell was operating in a relatively unusual way for a woman at the time. Bell's stepmother and sister stressed Bell's concern and respect for the conventions of Victorian society, but as Winstone has pointed out, Bell had a tendency as a young woman at Oxford, "to flout the accepted rules of conduct when her temper was roused or her sense of rightness was violated." ${ }^{104}$ Bell's involvement as secretary to the Women's National Anti-Suffrage League in 1908 would in some ways seem to suggest

\footnotetext{
${ }^{102}$ Szymaszek, 'Josef Strzygowski'.

${ }^{103}$ T. E. Lawrence, Letter to J. G. Wilson, in D. Garnett (ed.) Selected Letters of T. E. Lawrence (London, The Reprint Society, 1941), p. 249.

${ }^{104}$ H. V. F. Winstone, Gertrude Bell (London, Jonathan Cape, 1978), pp. 16-17.
} 
her support for this traditional position. ${ }^{105}$ And yet, a letter dated October 1910 published in the preface of Amurath to Amurath, Bell dedicated to Lord Cromer the volume which described her journey from Syria through Iraq to Turkey. ${ }^{106}$ This volume was published in 1911, a few months after Lord Cromer in December 1910 had become president of the newly formed National League for Opposing Women's Suffrage. In the same volume, as L. Cooper has shown, having sided with Strzygowski, Bell showed up the deficiencies in the work of his rival Herzfeld; while she herself was persuaded by some of Herzfeld's reasoning (about which he subsequently changed his mind!), Herzfeld criticised Bell for accepting Strzygowski's work uncritically". ${ }^{107}$ Here in Amurath to Amurath, as with the dedication to Strzygowski in the Thousand and One Churches, Bell was using her publications, and particularly their dedications, as an opportunity to bolster her position within an established elite by locating herself on particular sides within significant debates. Bell was known for standing up to others, but she also had to negotiate the attitudes of the men with whom, and often for whom, she was working. Lawrence's comments do not acknowledge Bell's unusual position as a woman in this context and they invite us to consider the extent to which, rather than having 'no great depth of mind', she was negotiating her position.

Gertrude Bell's archaeological research could only have been achieved by a person of great strength of character; her publications and archive preserve important discoveries recognised by other contemporaries at the time and since as considerable. It would appear however that, in spite of all her abilities, in her archaeological interpretation at Binbirkilise, Bell was influenced by an established authority to whom she dedicated the volume even though he had never been there himself. It is important that although she did not advance strongly the views

\footnotetext{
${ }^{105}$ Winstone, Gertrude Bell, p. 110.

${ }^{106}$ Bell, Amurath to Amurath, p. vii-ix.

${ }^{107}$ Cooper, ‘Archaeology and Acrimony', p. 149-155.
} 
about diffusion from the Orient to the west herself, she seems not to have argued against them, thereby indirectly facilitating the logical consequences of the approach. It is perhaps therefore interesting to note that in her archaeology, as perhaps also in her politics, her interpretations appear to have been crafted as offerings for the authorities by whom they would be received. This was perhaps part of Bell's strategy that enabled her to gain access to new people and environments where few women were given admittance. ${ }^{108}$

\footnotetext{
${ }^{108}$ I would like to thank members of BISI and participants at the Gertrude Bell Life and Legacy Conference and various colleagues including particularly Dr Kevin Greene, Prof Helen Berry, Prof Jim Crow, Dr Jane Webster and Dr Scott Ashley as well as an anonymous reviewer for stimulating conversations and helpful comments while this paper was in preparation.
} 